Egyptian Journal of Aquatic Biology \& Fisheries

Zoology Department, Faculty of Science,

Ain Shams University, Cairo, Egypt.

ISSN $1110-6131$

Vol. 24(7): 51 - 71 (2020)

www.ejabf.journals.ekb.eg

\title{
Properties and aerogel applications of a marine algal origin biocellulose produced by the immobilized Gluconacetobacter xylinus ATCC 10245
}

\author{
Hassan A.H. Ibrahim ${ }^{1}$, Maha M. Bassiouny Beliah², Aida M. Farag 3 , \\ Amani M.D. ElAhwany ${ }^{2 *}$ and Soraya A. Sabry ${ }^{2}$ \\ ${ }^{1}$ Marine Microbiology Department, National Institute of Oceanography and Fisheries (NIOF), \\ Alexandria, Egypt, \\ ${ }^{2}$ Department of Botany and Microbiology, Faculty of Science, Alexandria University, ${ }^{3}$ Marine \\ Biotechnology, NIOF, Alexandria, Egypt \\ "Corresponding Author( amanielahwany@yahoo.com)
}

\section{ARTICLE INFO}

Article History:

Received: Aug. 23, 2020

Accepted: Oct. 4, 2020

Online: Oct. 8, 2020

Keywords:

Biocellulose production,

G. xylinus,

Immobilization,

Aerogel applications,

Posidonia oceanic,
ABSTRACT

Algae are known to produce biomass faster as compared with lignocellulosic biomass. BC was produced by using reducing sugar from algae as a cheaper carbon source. The effect of immobilization on the production of biocellulose(BC) by Gluconacetobacter xylinus ATCC 10245 was studied. The BC production of all entrapped cultures within different gel materials was lower than that of free cell cultures but the entrapped $G$. xylinus cells in alginate beads recorded the highest BC productivity $(12.5 \mathrm{~g} / \mathrm{l})$. The adsorption of $G$. xylinus cells on luffa pulp (LP) and ceramics particles (CP) gave the highest BC production (14.5 $\mathrm{g} / \mathrm{l}$ ), which represents increasing of 1.14 and 1.05 - fold, respectively from the free cells. This attempt clarified that LP was the best immobilizing support as it gave the highest BC production. The effect of repeated reuse of LP was confirmed. Different physical properties of $\mathrm{BC}$ including; $\mathrm{pH}$, water absorption capacity, dissolving in several solvents, and chemicals were determined. Observation of BC through SEM analysis showed the fine cellulose ribbons (fibrils). The crystallinity for the BC produced from X-ray diffraction (XRD) spectra was $84 \%$. Upon the applicable level, the $\mathrm{BC}$ aerogel was formed to be applied in rising up the water and oil absorption capability by developing its hydrophilic properties. Data introduced strong affinities to the motor, olive, and cooking oils with high oil uptake contents of 7.5, 5.2, and $3.7 \mathrm{gg}^{-1}$, respectively. Moreover, the $\mathrm{BC}$ aerogel exhibited potential adsorption for different heavy metal ions $\mathrm{Pb}^{2+}, \mathrm{Cd}^{2+}$, and $\mathrm{Cu}^{2+}$. The highest capability of $\mathrm{Cd}^{2+}$ removal was $95.7 \%$ at $\mathrm{pH}$ 6. The biodegrability of our produced $\mathrm{BC}$ and then its safety was proven.

\section{INTRODUCTION}

In recent years, interest in algae is continuously increasing since algae have potential to meet global demand in addition to that microalgae have various advantages over other agricultural raw material (Szulczyk, 2010). Most significant is that they can be grown anywhere and under any weather conditions because algae have variety of species 
with different properties and adaptations ability. It can grow in open ponds, sea water, fresh water, deserts, arid lands, etc ( Goyat, 2012). Algae are known to produce biomass faster and on reduced land surface as compared with lignocellulosic biomass (Lee, 2013). The cell wall of algae consists of polysaccharides that can be hydrolyzed to produce sugar. Therefore, algae can be used as a carbon source in fermentation processes. All these characteristics make algae a promising alternative for agricultural residues (Goyat, 2012). BC was produced by using reducing sugar from algae as a cheaper carbon source (Beliah et al., 2020). Biocellulose (BC) is produced by an acetic acid-producing bacterium; Gluconacetobacter xylinus with a diameter of about $1 / 100$ of that of plant cellulose (Esa et al., 2014). Currently, different kinds of microbial immobilization have found wide applications in many fields (biotechnology, pharmaceutical, environmental, food, and biosensor industries). By immobilization, microorganisms may retain on a carrier can be used in continuous and semi-continuous production processes allowing for significant cost decrease, as the biocatalyst does not need to be refilled (Mrudula and Shyam, 2012).

The carriers are classified as inorganic material (such as: zeolite, clay, anthracite, porous glass and ceramics) and organic polymers (such as: alginate, carrageenan, agar, collagen, gelatin, cellulose, polyacrylamide, polyester, polystyrene, and polyurethane). The most commonly used polymers are the natural polymers alginate and carrageenan but these natural polymers are less stable in wastewater than synthetic polymers (Stolarzewicz et al., 2011).

However, the entrapment is the most method extensively studied in cell immobilization. It is also an irreversible process, where immobilized cells are entrapped in a support matrix or inside fibers. This technique creates a protective barrier around the immobilized microbes, ensuring their prolonged viability during not only processing but also storage in polymers (Górecka and Jastrzębska, 2011).

On the other side, the BC has many properties such as high degree of crystallinity, high purity, high density, high water binding capacity, good shape retention, and higher surface area as compared to the native cellulose. It can be used in various areas including paper, textile industry, pharmaceutical, food, waste treatment, mining, and refinery (Shah and Brown, 2005; Czaja et al., 2006).

Particularly, aerogel is officially defined as gel comprised of microporous solid, in which the dispersed phase is a gas (Alemán et al., 2006). Because of the abundant choices of raw materials and the highly porous structure with mechanical strength, aerogels possessing significant features have been employed for many versatile applications (Tan et al., 2001). Network gels were formed by cross-linking cellulose acetate and cellulose acetate butyrate with tolylene 2,4-diisocyanate. However, they claimed that cellulose aerogels were not adequate to form carbon aerogels due to their rapid decomposition during pyrolysis. Ironically, a type of ultralight and flexible carbon aerogels were produced by pyrolyzing bacterial cellulose foams (Wu et al., 2014). In addition, cellulose based aerogels have also been used as adsorbents to remove pollutants from aqueous systems (Zhao et al., 2015).

Therefore, the current study aimed to investigate the influence of immobilization on the production of BC by Gluconacetobacter xylinus ATCC 10245 and its different properties. As well as, it conducted to some potential applications by using the BC aerogel prepared from this bacterium. 


\section{MATERIALS AND METHODS}

\section{Bacterial strain used for $\mathrm{BC}$ production and culture media}

Bacterial strain used throughout this study was Gluconacetobacter xylinus ATCC 10245, which was obtained from Microbial Culture Collection, Microbiological Resources Center (Cairo MIRCEN), Faculty of Agriculture, Ain Shams University, Egypt.

The bacterial strain was maintained on glucose yeast calcium carbonate (GYC) agar slants, stored at $4^{\circ} \mathrm{C}$ and subcultured every two weeks to maintain good viability and stability for the $\mathrm{BC}$ production.

From previous work regarding optimization of the BC production by Gluconacetobacter xylinus ATCC 10245 (Beliah, 2017); reducing sugar was extracted from algae; Posidonia oceanic treated with $1 \% \mathrm{H}_{2} \mathrm{SO}_{4}$ as a marine-origin carbon source. Consequently, the optimized medium contained (g/l): reducing sugar, 30; yeast extract, 7 ; peptone, 7; dibasic sodium phosphate (buffer), 3.7; citric acid, 0.2 under static condition within incubation period of 10 days.

\section{Saccharification process using submerged fermentation}

The submerged fermentation process was carried by medium containing pretreated substrate. A volume of $100 \mathrm{ml}$ of aged filtered sea water amended with $3 \mathrm{~g}$ from pretreated substrate as sole carbon source and inoculated with a volume of $100 \mathrm{ml}$ of sterile modified Czapek's-Dox broth medium was added to $3 \mathrm{~g}$ from pretreated substrate as sole carbon source and inoculated with $3 \mathrm{ml}$ freshly prepared inoculum. The flasks were loaded on a rotary shaker incubator at a speed of $120 \pm 2 \mathrm{rpm}$ at $28^{\circ} \mathrm{C} \pm 2^{\circ} \mathrm{C}$ for 6 days. After incubation, the production broths were centrifuged at $5000 \mathrm{rpm}$ for 15 $\mathrm{min}$. The supernatants were collected for determining the reducing sugars concentration and enzymatic activity (El-Naggar et al., 2014).

\section{Estimation of reducing sugars}

The amount of reducing sugars was estimated by dinitrosalicylic acid method (Miller, 1959). $0.5 \mathrm{ml}$ of sample was drawn from every sample into test tubes. The volume was made up to $3 \mathrm{ml}$ using distilled water. Dinitrocsalicylic acid (DNSA) reagent of $3 \mathrm{ml}$ were added to each sample and mixed well. The reagent blank containing $3 \mathrm{ml}$ of distilled water and $3 \mathrm{ml}$ of DNSA reagent was also prepared. Similarly, standards were also included whose glucose concentration ranged from 200 to $1000 \mu \mathrm{g}$. All tubes were kept on boiling water bath for $15 \mathrm{~min}$. After this, one.ml of $40 \%$ Rochelle salt solution was added when the reaction mixture was still warm. Then the tubes were cooled. The samples were read at at the wave length $510 \mathrm{~nm}$. Glucose was used as the standard for this analysis.

\section{Immobilization of G. xylinus ATCC 10245 cells by entrapment}

Gluconacetobacter xylinus ATCC 10245 cells were entrapped within four organic matreces (alginate, carragennen, agar, and agarose). In the frist matrix, the cells were entrapped in 3\% calcium alginate gel as described by Sankaralingam et al. (2012). Secondly, the bacterial cells were entrapped in $3 \%$ k-carragennen gel as described by 
Wada et al. (1980). To entrap the cells in the agar and agarose, the gel was prepared by dissolving $0.9 \mathrm{~g}$ of agar or agarose in $27 \mathrm{ml}$ distilled water. After sterilization of the solution (by autoclaving at $121^{\circ} \mathrm{C}$ for $20 \mathrm{~min}$ ), three $\mathrm{ml}$ of bacterial cells were added to the gel solution and $10 \mathrm{ml}$ were poured into sterilized petri dish. After solidification, the gel was cutted with a sterile cutter into small cubes, then transferred into $30 \mathrm{ml}$ of sterilized medium and incubated at $30^{\circ} \mathrm{C}$ for 15 days under static conditions.

\section{Immobilization of $G$. xylinus ATCC 10245 cells by adsorption}

One $\mathrm{ml}$ of bacterial cells was added to $30 \mathrm{ml}$ of sterilized culture medium and about 10 cubes of synthetic sponge cubes (SSC) or luffa pulb (LP) or clay and pumice particles in $100 \mathrm{ml}$-Erlenmeyer flasks. The flasks were incubated at static condition for 15 days at $30^{\circ} \mathrm{C}$ (Vassilev et al., 1993). At the end of incubation time, sugar consumption and $\mathrm{BC}$ production were determined.

\section{Reusing of the immobilized G. xylinus ATCC 10245 cells}

The best immobilized bacterial cells that gave the highest production of $\mathrm{BC}$ were reused for several cycles in a fermentation medium containing 10 cubes of LP and supplmented with one $\mathrm{ml}$ of bacterial suspensionm incubated at $30^{\circ} \mathrm{C}$ for 15 days at static conditions. The reused of the adsorbed cells was carried out by removing the medium after 15 - days and a new sterilized medium $(30 \mathrm{ml})$ was added, then a $2^{\text {nd }}$ cycle was run at the optimum conditions.this process was repeated. At the end of each cycle, the BC production and sugsr consumption were determined.

\section{Physicochemical properties of the produced BC}

The BC powder was mixed with distilled water and allowed to stand with occasional stirring for one hour. Thereafter, the liquid supernatant was collected and the $\mathrm{pH}$ of the liquid was tested using $\mathrm{pH}$ meter. For solubility test, $250 \mathrm{mg}$ of BC powder were separately mixed with sodium hydroxide, methanol, acetone and cupriethylenediamine (Cuen). The solubility of the fiber in each solvent was then observed (Halib et al., 2012). In order to determine the water absorption capacity (WAC), the dried BC samples were immersed in water at room temperature. Then, the samples are taken out from the water and excess water left on the BC surface is blotted out with Kimwipes paper. After that, the weights of the hydrated BC samples were measured. The procedure was repeated till no further weight change (Junaidi et al., 2012). The water content is calculated using the following formula: WAC $(\%)=[(\mathrm{Wh}-\mathrm{Wd}) / \mathrm{Wd}] \times 100 \%$, where $\mathrm{Wh}$ and $\mathrm{Wd}$ indicate the weight of the hydrated and dried $\mathrm{BC}$ samples, respectively.

\section{Scanning Electron Microscopy (SEM) analysis}

Microscopic photographs of the adsorbed G. xylinus on the best solid support and also The BC sample were prepared and then examined using SEM (Jeol.Jsm-5300), (Central Laboratory, Faculty of Science, Alexandria University, Egypt). However, the BC sample was sputtered coated with gold and examined at $15000 \times$ magnification for surface view of $\mathrm{BC}$. The same procedure was carried out for $\mathrm{BC}$ dried sheet sample, but using $10000 \times$ magnification (Halib et al., 2012). 


\section{X-ray analysis}

The X-ray diffraction (XRD) was used to examine the crystallinity degree of the BC. It was performed with a Rigaku Smart lab XRD (Rigaku, The woodlands, TX Central Laboratory, Faculty of Science, Alexandria, Egypt) using $\mathrm{Cu}$ radiation generated at $40 \mathrm{kv}$ and $44 \mathrm{~mA}$. The Bragg angle of $2 \theta$ was scanned from $9^{\circ}$ to $41^{\circ}$ with a step and exposure time of $5 \mathrm{~s}$. Freeze dried samples $20 \mathrm{mg}$ were used for analysis (Moosavi-Nasab et al., 2011). The crystallinity index (C.I.) was calculated from the reflected intensity data using the Segal method, according to the following eqation (Keshk and Sameshima, 2006): $\left.\mathrm{C}_{\mathrm{Ir}}(\%)=\left\{\left(\mathrm{I}_{002}-\mathrm{I}_{\mathrm{am}}\right) / \mathrm{I}_{002}\right)\right\}^{*} 100$, where $\mathrm{I}_{002}$ is the maximum intensity of the lattice diffraction and $\mathrm{I}_{\mathrm{am}}$ was the intensity at $2 \theta=18^{\circ}$.

\section{Mechanical properties of the produced $\mathrm{BC}$}

The mechanical properties of the $\mathrm{BC}$ pellicles were analyzed through uniaxial tensile tests, using a testing machine Zwicki $2.5 \mathrm{KN}$, Sadex Technical Consulting and Agencies, Alexandria, Egypt. Using the Bluehill software, connected to the testing machine, it was sufficient to insert the dimensions of the samples before the beginning of the experiments, and the software calculated automatically the values of stress, strain and Young's modulus during the test (Keshk and Sameshima, 2006).

\section{Applications of the produced $\mathrm{BC}$ via formating aerogel}

The aerogel was formed to be applied in several potential applications such as; water and oil absorption. Water absorption capability needed to develop the hydrophilic properties of $\mathrm{BC}$ aerogel, while the oil absorption nedded to develop the hydrophobic properties of $\mathrm{BC}$ aerogel. Furthermore, the adsorption of heavy metal ions from aqueous solutions using $\mathrm{BC}$ aerogel was studied.

\section{Development of hydrophilic BC aerogel and water absorption test}

The $\mathrm{BC}$ aerogel was formed firstly to be used in such test and other followed testes. The BC (2\%) was dispersed into sodium hydroxide/urea solutions $(1.9 / 10, \%)$ by sonicating for $6 \mathrm{~min}$. Thereafter, the solution was placed in a refrigerator for more than $24 \mathrm{~h}$ to allow gelation of the solution. After the solution has been frozen, it is then thawed at room temperature and then followed by immersing into ethanol (99\%) for coagulation. The specimen thickness was controlled at $1 \mathrm{~cm}$ with a diameter of $3.5 \mathrm{~cm}$ using a beaker as a mold. After coagulation, solvent exchange was carried out by immersing the gel in de-ionized water for two days. The sample was then frozen in a freezer at $-18^{\circ} \mathrm{C}$ for $12 \mathrm{~h}$. After that freeze drying was carried out for two days with freeze dryer to obtain the desired aerogel (Nguyen et al., 2014).

Water absorption capability of aerogel samples was investigated in deionoized water. The dry sample dimensions were $40 \mathrm{~mm}$ (diameter) $\times 12 \mathrm{~mm}$ (thickness). The dry sample was weighed and immersed in $800 \mathrm{ml}$ of de-ionized water for a certain time. The wet sample was weighed, dried or squeezed and weighed again. The test was repeated 
three times with an immersion time of $2 \mathrm{~h}$. To dry the aerogel, it takes seven days for the absorbed water to evaporate naturally under the atmosphere conditions (Nguyen et al., 2014).

\section{Development of hydrophobic $\mathrm{BC}$ aerogel and oil absorption test}

For hydrophobic coating, the BC aerogel was placed in a big glass bottle. A small open glass vial containing methyltrimethoxysilane (MTMS) was added into the glass bottle. Then, the glass bottle was capped and heated in an oven at $70^{\circ} \mathrm{C}$ for $2 \mathrm{~h}$ for the silanation reaction. Thereafter, the coated sample was placed in a vacuum oven to remove the excess coating reagent (Nguyen et al., 2014). The test was similar to the water absorption test except that the excess oil was allowed to drain for $30 \mathrm{~s}$ after lifting up the wet sample. Motor oil with a viscosity of $130 \mathrm{cP}$, an olive oil with a viscosity of $100 \mathrm{cP}$ and cooking oil with a viscosity of $55 \mathrm{cP}$ were used in the test (Nguyen et al., 2014).

\section{Adsorption of heavy metal ions from aqueous solutions using BC aerogel}

Adsorption process was performed under static conditions along $48 \mathrm{~h}$ at room temperature using $1 \mathrm{~g}$ of adsorbent with $0.1 \mathrm{~mm}$ grain-size and $100 \mathrm{ml}$ of metal solution ions $(20 \mathrm{mg} / \mathrm{l})$. Concentration of $\mathrm{Cd}^{2+}, \mathrm{Pb}^{2+}$, and $\mathrm{Cu}^{2+}$ was determined using atomic absorption spectroscopy (Chemical lab, National Institute of Oceanography and Fisheries (NIOF), Alexandria, Egypt). Amount of adsorbed metal was calculated from the equation: $\mathrm{Q}=\left(\mathrm{C}_{\mathrm{o}}-\mathrm{C}_{\mathrm{e}}\right) \mathrm{V} / \mathrm{m}$, Where: $\mathrm{Q}$ is amount of adsorbate adsorbed on the adsorbent, $\mathrm{mg} / \mathrm{g} ; \mathrm{C}_{\mathrm{o}}$ is initial concentration of adsorbate, $\mathrm{mg} / \mathrm{ml} ; \mathrm{C}_{\mathrm{e}}$ is concentration of adsorbate at equilibrium state, $\mathrm{mg} / \mathrm{ml}$; $\mathrm{m}$ is mass of the adsorbent, $\mathrm{g}$; $\mathrm{V}$ is volume of aqueous solution, 1. (Chen et al., 2010). Removal efficiency (R) $\%=\left[\left(\mathrm{C}_{\mathrm{o}}-\mathrm{C}_{\mathrm{e}}\right) / \mathrm{C}_{\mathrm{o}}\right] \mathrm{x} 100$.

\section{Biodegradation of the produced BC}

To prove the biodegrability of the present BC and then its safety, $100 \mathrm{mg}$ of its sheet were mixed with $50 \mathrm{ml}$ of waster sample from different sources (Nile water and seawater) or mixed with $50 \mathrm{~g}$ of marine sediment or garden soil. The efficacy of biodegradation process was detected by determining the total bacterial count $(\mathrm{CFU} / \mathrm{ml})$ along $0,5,10$, and 15 days interval. Also, the glucose concentration was initially estimated as $1 \mathrm{mg} / \mathrm{l}$, and then estimated finally again.

\section{RESULTS}

\section{Effect of entrapping cells with different gel materials on BC production}

Different gel materials were used for entrapping G. xylinus ATCC 10245 cells. The gel entrapping the bacterial cells was usually in the form of beads in the case of Caalginate $(2 \%)$ and k-carragennan $(2 \%)$, while agar and agarose gel were in the form of small cubes (about $0.5 \mathrm{~cm}$ length). The results recorded in Figure 1, supported that the $\mathrm{BC}$ production of all entrapped cultures was lower than that of free cell cultures. The BC 
produced by entrapped G. xylinus ATCC 10245 in alginate beads recorded the highest productivity $(12.5 \mathrm{~g} / \mathrm{l})$ comparing to other entrapped cells, while the k-carragennan gave the lowest BC production $(9.3 \mathrm{~g} / \mathrm{l})$.
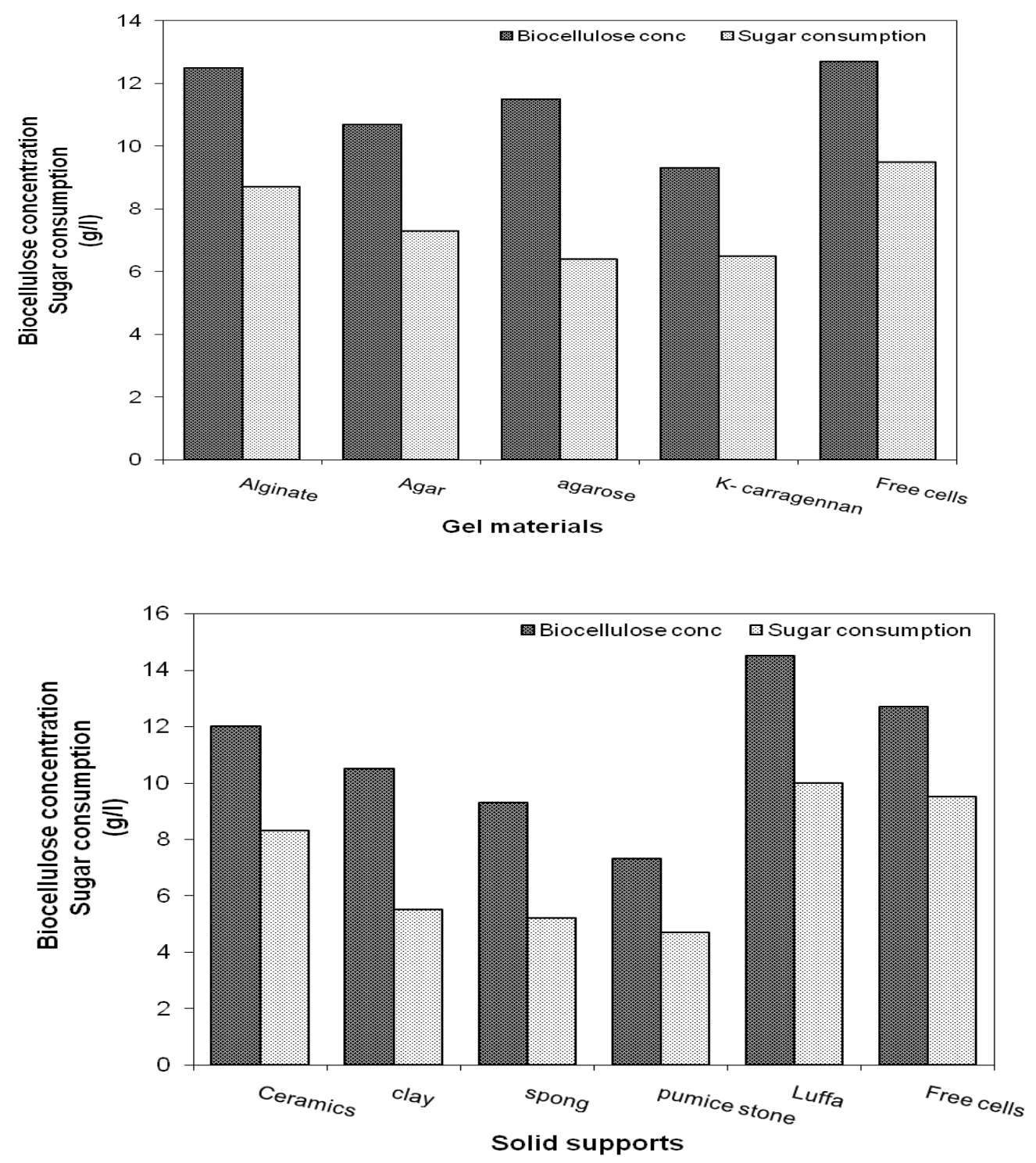

Fig.1: Production of BC and sugar consumption by G. xylinus ATCC 10245 entrapped on different gel materials (Upper) and adsorbed on different porous supports (Lower).

\section{Effect of adsorption of G. xylinus ATCC 10245 cells on BC production}

Data of this experiment conducted to the cells were adsorbed on SSC, LP, PP, CP, and CP. The results graphically illustrated in Figure1,revealed that the adsorption of $G$. xylinus ATCC 10245 cells on LP and CP gave the highest BC production (14.5 g/l) and sugar consumption $(10.0 \mathrm{~g} / \mathrm{l})$, respectively. This represents increasing of 1.14 and 1.05fold, respectively from free cells. On the other hand, other solid supporters produced 
lower BC production. The illustrated attempt to immobilized G. xylinus ATCC 10245 cells by entrapment and adsorption mechanism clarified that LP was the best immobilizing support as it produced the highest $\mathrm{BC}$ production, while immobilizing bacterial cells by k-carragennan, pumice, and synthetic sponge recorded the lowest $\mathrm{BC}$ production $(9.2,7.3$, and $9.5 \mathrm{~g} / \mathrm{l}$, respectively).

\section{Production of BC by reused adsorbed G. xylinus ATCC 10245 cells}

The effect of repeated reuse of LP as the best adsorbed solid support for the BC production by G. xylinus ATCC 10245 was examined. The results shown in Figure 2 indicated that the reused of the adsorbed G. xylinus ATCC 10245 cells on LP slightly enhanced the $\mathrm{BC}$ production in the culture medium of $2^{\text {nd }}$ run $(15.7 \mathrm{~g} / \mathrm{l})$, then the reused culture showed gradually decrease in the $\mathrm{BC}$ production up to the $4^{\text {th }}$ run; where the adsorbed G. xylinus ATCC 10245 cells exhibited the lowest BC production (11.5 g/l).

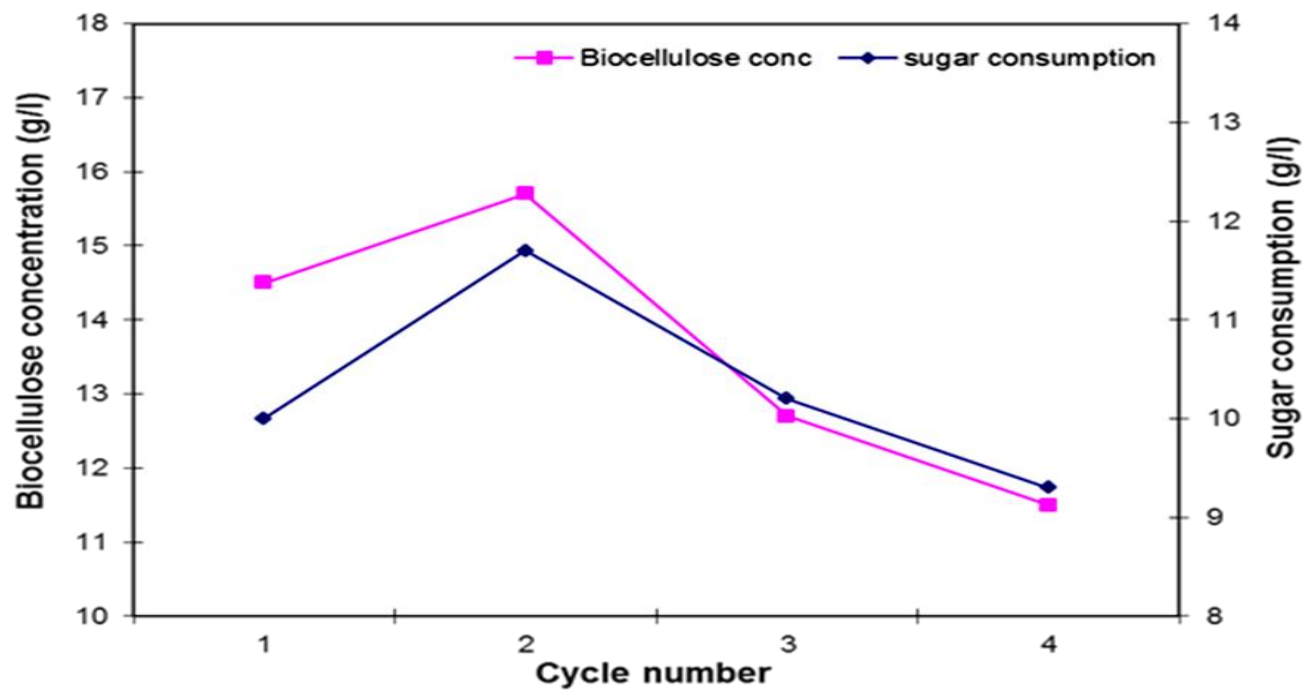

Fig. 2: Production of BC and sugar consumption by reused adsorbed $G$. xylinus ATCC 10245 cells.

\section{SEM micrographs of adsorbed G. xylinus ATCC 10245 cells}

According to SEM micrographs, Figure 3 shows that there is a high condense of G. xylinus cells on surface of the LP. The micrographs indicate the good adsorption of $G$. xylinus cells to the surface of supporting material with different degree, so that, it could emphasis the explanation of high $\mathrm{BC}$ production resulted due to adsorption on LP. 


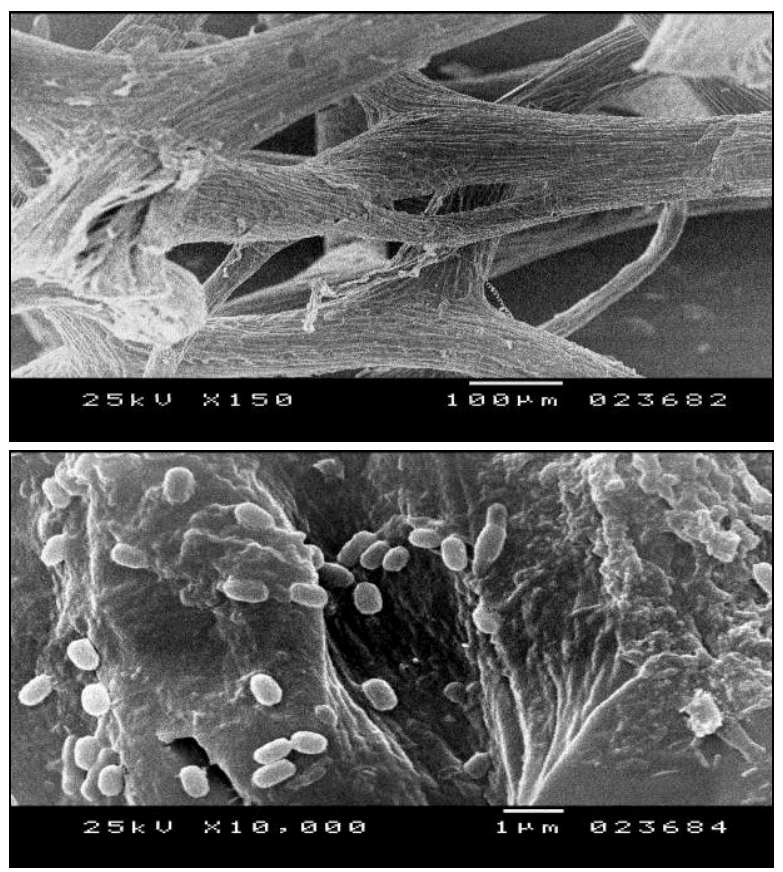

Fig. 3: SEM micrographs showing the structure of LP (Upper), and G. xylinus ATCC 10245 cells adsorbed on the surface of LP matrix (Lower)

\section{Physico-chemical properties of $G$. xylinus ATCC 10245 BC}

The $\mathrm{pH}$ of the supernatant liquid from the $\mathrm{BC}$ and distilled water mixture was determined to be $\mathrm{pH}$ 7.3. The physical observation showed that the $\mathrm{BC}$ powder did not dissolve in solvents such as sodium hydroxide, methanol, and acetone. Indeed, it completely dissolved in cupriethylenediamine (Cuen). The water absorption capacity for each of the BC produced from sea grasses media was $199 \%$.

\section{SEM analysis of G. xylinus ATCC 10245 BC}

This analysis was applied to examine the surface features of BC nanofibers produced by G. xylinus ATCC 10245. Data represented in Figure 4, exhibited the surface view for the BC nanofiberils, which can't be observed due to converge by thick layers. In paricular, it has well interconnected pore network structure. All these made the BC fibrous with irregular size and shape. It was observed that the BC shown with fine cellulose ribbons, sometimes called fibrils. 

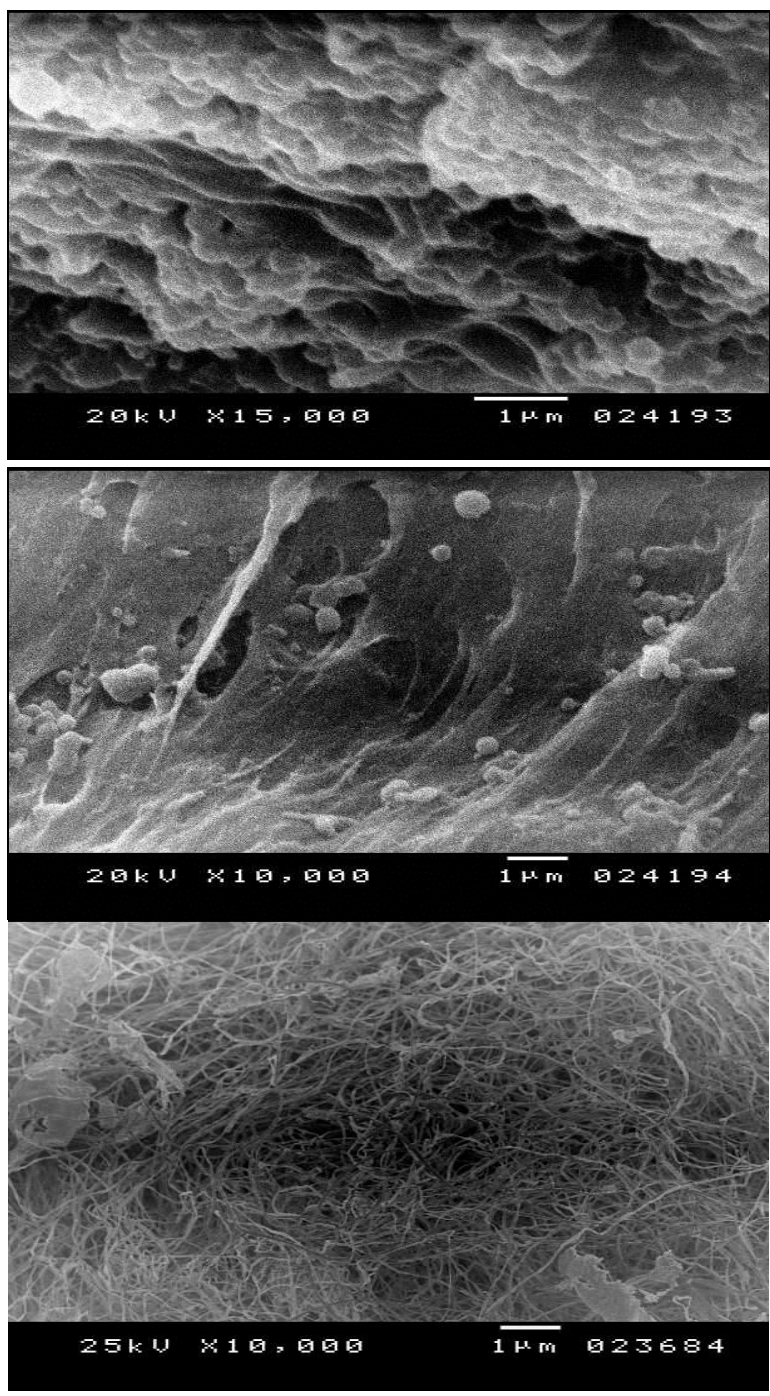

Fig. 4: SEM micrographs of BC produced by G. xylinus ATCC 10245; BC surface (Upper), BC dried sheet (Middle) and BC fibril network (Lower)

\section{$X$-ray analysis of BC produced by $G$. xylinus ATCC 10245}

The crystalline index values of BC were calculated from XRD spectra using amorphous region subtraction. The resulting spectra were analyzed and normalized (Figure 5). The crystallinity for the produced BC was $84 \%$. 


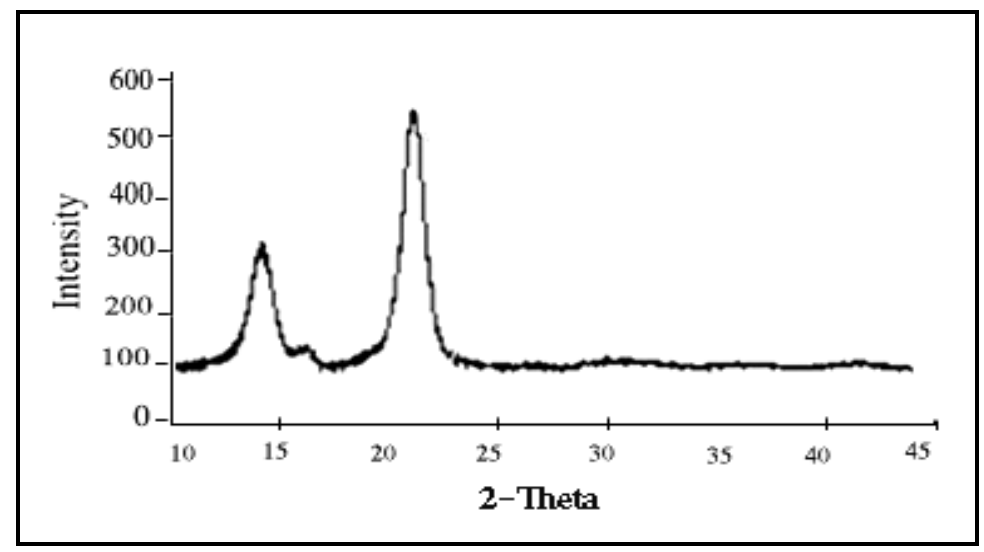

Fig. 5: X-ray patterns of BC produced by G. xylinus ATCC 10245.

\section{Tensile strength BC produced by G. xylinus ATCC 10245}

Tensile strength of the BC produced by G. xylinus ATCC 10245 was determined for studying mechanical properties, which are summarized in Table (1). However, they revealed the good quality of our product.

Table 1: Tensile tests on BC produced by G. xylinus ATCC 10245.

\begin{tabular}{lc}
\hline Parameter & Value \\
\hline Specimen thickness $(\mathrm{mm})$ & 0.11 \\
Specimen width $(\mathrm{mm})$ & 14 \\
Tensile strength $(\mathrm{MPa})$ & 22.7 \\
Young's modulus $(\mathrm{Mpa})$ & 349.5 \\
\hline
\end{tabular}

\section{Applications of the produced BC by formating aerogels}

The formed BC aerogel was used in some significant and valuable applications in rising up the water absorption capability, the oil absorption and adsorpting selected heavy metals from aqueous solutions.

\section{SEM analysis of the produced BC aerogel}

It was observed that the BC aerogel and SEM analysis of freeze-dried BC aerogel revealed its highly porous network structure (Figure 6). 


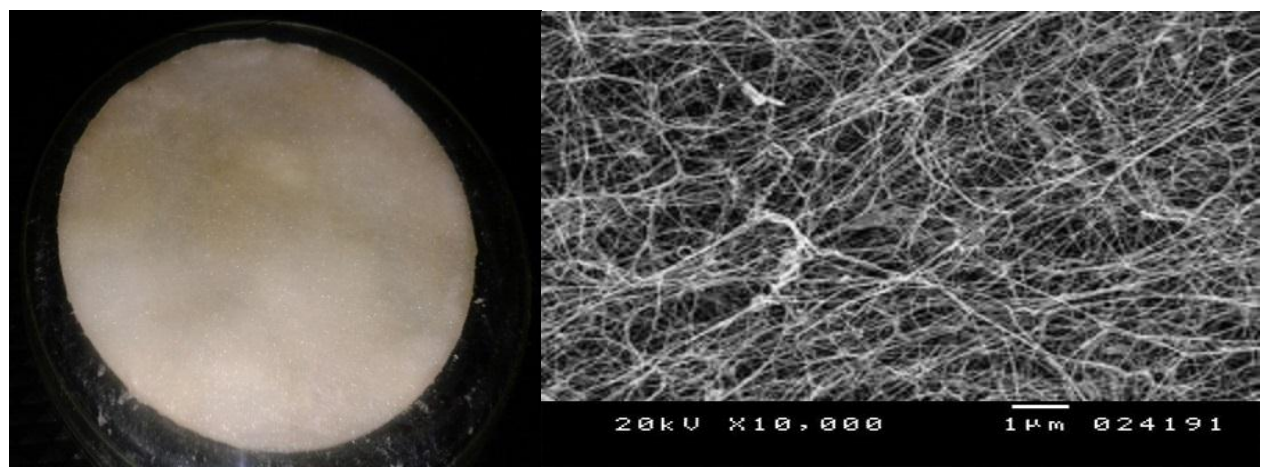

Fig. 6: BC produced by G. xylinus ATCC 10245; aerogel (Left) and SEM image of BC aerogel (Right).

\section{Water absorption test}

The water absorption of $\mathrm{BC}$ aerogel was studied in two phases. In the first phase, water absorption ability of $\mathrm{BC}$ aerogel was measured each $15 \mathrm{~min}$ for $2 \mathrm{~h}$. In the second one, the aerogel sample was subjected to three cycles of water absorption tests using a dip coater for $2 \mathrm{~h}$. The weight of the sample was measured before and after each test (Table 2).

Table 2: Water absorption test with various absorbance times.

\begin{tabular}{lcccc}
\hline Phase & $\mathbf{m}_{\mathbf{d}}(\mathbf{g})$ & $\mathbf{m}_{\mathbf{w}}(\mathbf{g})$ & $\mathbf{m}_{\mathbf{s}}(\mathbf{g})$ & WAC $(\boldsymbol{\%})$ \\
\hline First absorption & 1 & 7.3 & 0.97 & 630 \\
Second absorption & 0.97 & 7 & 0.97 & 622 \\
Third absorption & 0.95 & 6.8 & 0.95 & 616 \\
\hline
\end{tabular}

$\mathrm{m}_{\mathrm{d}}$, weight of initial sample; $\mathrm{m}_{\mathrm{w}}$, weight of wet sample; $\mathrm{m}_{\mathrm{s}}$, weight of dried or squeezed sample.

\section{Oil absorption test}

The MTMS-coated BC aerogel exhibited strong affinities to the motor, olive, and cooking oils with high oil uptake contents of 7.5, 5.2, and $3.7 \mathrm{gg}^{-1}$, respectively (Fig.7).

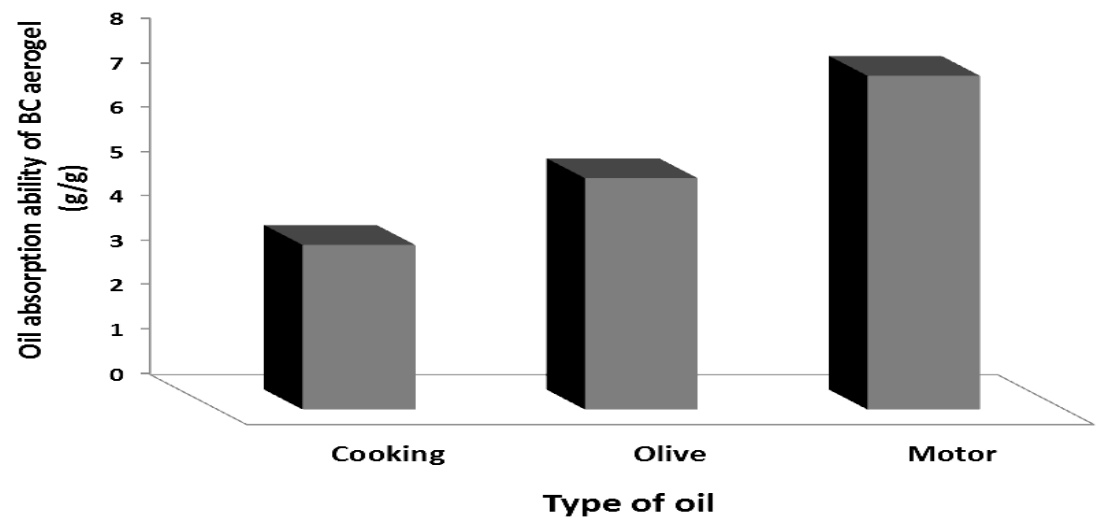

Fig.7: Oil absorption ability of the BC aerogel towards motor, olive, and cooking oils. 


\section{Adsorption of heavy metal ions from aqueous solutions using BC aerogel}

The $\mathrm{BC}$ aerogel was characterized by high sorption capacity for $\mathrm{Cd}^{2+}$ comparing to other metal ions. It showed the highest capability of $\mathrm{Cd}^{2+}$ removal (95.7\%) at $\mathrm{pH} 6$ (Table 3).

Table 3: Removal efficiency and sorption capacity of heavy metals on BC aerogel at different $\mathrm{pHs}$.

\begin{tabular}{ccccccc}
\hline \multirow{2}{*}{$\mathbf{p H}$} & \multicolumn{3}{c}{ Removal efficiency $(\mathbf{R} \%)$} & \multicolumn{3}{c}{ Sorption capacity; $\mathbf{Q}(\mathbf{m g} / \mathbf{g})$} \\
\cline { 2 - 6 } & $\mathbf{P b}^{2+}$ & $\mathbf{C d}^{2+}$ & $\mathbf{C u}^{2+}$ & $\mathbf{P b}^{2+}$ & $\mathbf{C d}^{2+}$ & $\mathbf{C u}^{2+}$ \\
\hline 4 & 70 & 94.7 & 94.1 & 1.41 & 1.89 & 1.88 \\
5 & 74 & 95.5 & 94 & 1.48 & 1.9 & 1.88 \\
6 & 76 & 95.7 & 94.6 & 1.52 & 1.91 & 1.89 \\
7 & 68 & 94.4 & 93.7 & 1.36 & 1.88 & 1.87 \\
\hline
\end{tabular}

\section{Biodegradation of the produced $\mathrm{BC}$}

The biological effect of some means such as freshwater, seawater, marine sediment, and garden soil microbes was determined on the BC produced by G. xylinus ATCC 10245. The total bacterial count increased periodically between zero and 15-days incubation. The $\mathrm{BC}$ with the Nile water had the highest count $\left(1.2 \times 10^{12} \mathrm{CFU} / \mathrm{ml}\right)$, followed by the garden soil treatment $\left(1.1 \times 10^{11} \mathrm{CFU} / \mathrm{ml}\right)$, while, the other two treatments had count around $1.0 \times 10^{9} \mathrm{CFU} / \mathrm{ml}$ (data not shown). The final glucose concentration after 15-days incubation was $17,15,10$, and $7 \mathrm{mg} / \mathrm{l}$, for Nile water, seawater, soil, and marine sediment, respectively. However, it was shown that freshwater microbes had the highest effect for the BC biodegradation (Figure 8).

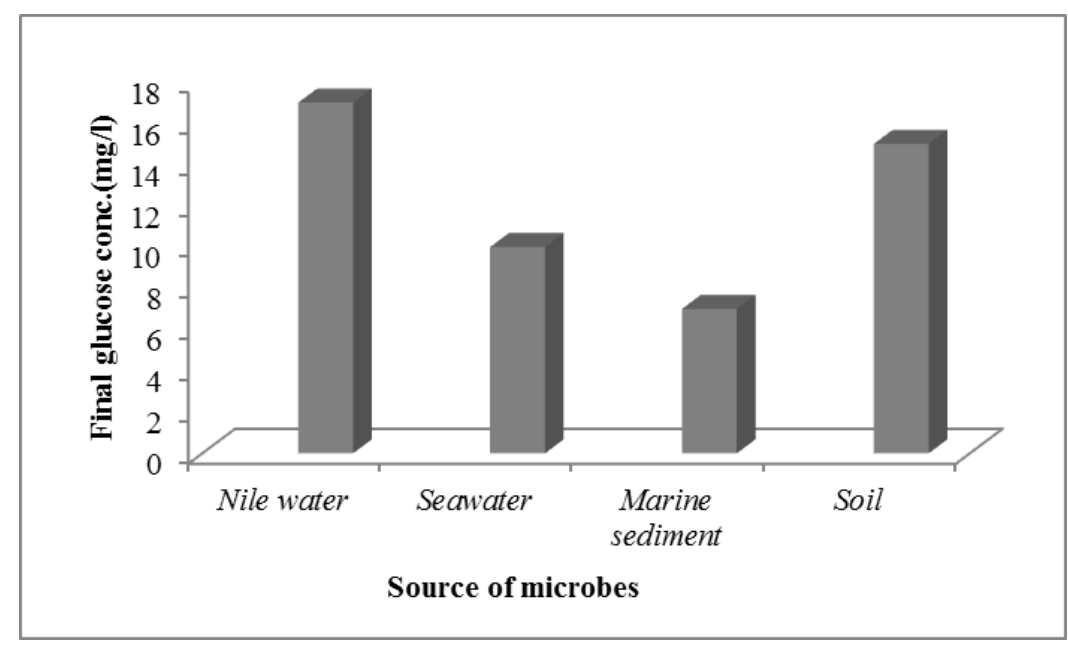

Fig. 8: The final glucose concentration as a factor for the biodegradation of the $\mathrm{BC}$ produced by G. xylinus using different environmental microbes. 


\section{DISCUSSION}

Gluconacetobacter xylinus ATCC 10245 is usually the most employed microorganism for producing biocellulose because of its ability to produce relatively high levels of polymer from a wide range of carbon and nitrogen sources (Bielecki et al., 2005). This bacterium produces cellulose from a wide variety of substrates and is devoid of cellulase activity (Chawla et al., 2009; Hungund et al., 2013).

Several workers (Zeng et al., 2011; Wu and Liu, 2012) have used the batch culture for the $\mathrm{BC}$ production. Batch culture is preferred having fewer parameters to be controlled and well understood. So, all experiments during this study were done in batch culture.

The cheaper substrate used instead of the commonly used sugars as glucose or fructose might result in a lower cost of the final product. So, the medium with reducing sugars came from saccharification of $U$. lactuca supported the highest production of BC (3.7 g/l) (Beliah, 2017).

The immobilized $G$. xylinus cells by different techniques (entrapment and adsorption) were applied for $\mathrm{BC}$ synthesis. The production of biopolymers by immobilized bacteria using different materials were studied well (Berekaa et al., 2009). Reusing of microbial cells aimed to enhance the cell population and activity (Chitturi and Lakshmi, 2016).

The works of both Suwannapinun et al. (2007) and Enas et al. (2015) had reported that the native Gluconacetobacter pellicle had mechanical properties including shape retention and tear resistance that was superior to many synthetic fibers. According to British Pharmacopoeia, pure cellulose should have $\mathrm{pH}$ of supernatant liquid around $\mathrm{pH}$ (5-7.5) (Halib et al., 2012).

The powder completely dissolved in cupriethylenediamine (Cuen), was considered the best well known solvent for cellulose (Halib et al., 2012). As well as, ethylenediamine is a good swelling agent for cellulose. By disrupting intermolecular hydrogen bond, swelling promotes molecular chain separation allowing thorough penetration of the solvent. This process had enhanced the complex formation with cellulose glycol groups. The complex is sufficiently stable to prevent aggregation of chains and formation of precipitation. Therefore cellulose was being dissolved (Johnson, 1985). Hence the results supported that cellulose is the primary component of the bacterial cellulose powder.

The WHC is considered one of the most important physical characteristics of bacterial cellulose pellicles regarding biomedical application of $\mathrm{BC}$ as wound dressing material. Biocellulose has a high WHC in compared to cellulose plant. This is due to the fact that hydrogen bonding is stronger and more BC cellulose chain (n) long from plant cellulose (Mohammad et al., 2014). The variations between the WHC are related to the porosity and surface area of each BC. The greater the surface area and the pore size the larger the amount of water penetrated and trapped in the $\mathrm{BC}$ matrix (Ul-Islam et al., 
2012). The WHC of our BC provides a special nano-morphology results that lead to the remarkable water absorbing ability of the $\mathrm{BC}$. These findings are in agreement with previous reports showing that microbial cells have the potential to absorb more than 100 times their dry weight in water (Lin et al., 2009). The WHC of the BC produced in the current study are in good agreement with study of Ullah et al. (2016) and sometimes even higher (Jung et al., 2005).

The SEM analysis of indicates that the BC surface nanofiberils can not be observed due to converge by a thick layers. So, it has well interconnected pore network structure (and BC dried sheet, the biocellulose was fibrous with irregular size and shape. Similar observation has been previously reported by Nge et al. (2010) and Halib et al. (2012).

Obviously, the BC fibril network produced by G. xylinus ATCC 10245 was observed. The fibers were loosely arranged with large pores in BC. Moreover, a randomly distributed condensed network of fibrils was observed. A magnified image (1 $\mu$ ) further clarified that the fibrils were thin and possessed plenty of gaps between them. Similar observation has been previously reported by Ullah et al. (2016). SEM images of BC fibers, showed more delicacy. The higher delicacy of the BC fibers could influence its properties such as WHC, thermal stability, and mechanical strength. For instance BC has a higher tensile strength, mold ability and WHC (Jung et al., 2005).

Biocellulose is a semi-crystalline material that usually produces three major characteristic crystallinic peaks when examined through XRD (Ullah et al., 2016). It showed that XRD spectrum for our BC was similar to advanced reports (French, 2014; Khan et al., 2015). Moreover, the crystallinity degree of the produced BC in this study was in good agreement with work of Tsouko et al. (2015) and sometimes even higher (Ullah et al., 2016).

The tensile strength and young's modulus of our BC were similar to obtained by Suwanposri et al. (2014) and sometimes even higher than those obtained by Ullah et al. (2016). However, the fibers of BC are thicker, and more compact. The thicker fibers and compact structure could be attributed to the continuous production and aggregation of glucose chains with the passage of time as reported previously by Mormino and Bungay (2003). This compactness and uniform arrangement of fibrils in BC could favor a uniform response to the applied force and result in its improved tensile strength (Ul-Islam et al., 2012). The nano sized network wires promotes high surface area, Due to its properties BC can be used in nature, like nanocrystals form or associated with other natural or synthetic polymers to obtain biodegradable materials (Schröpfer et al., 2015).

Since bacterial cellulose has many properties like high degree of crystallinity, high purity, good shape retention, high density, high water binding capacity, and higher surface area as compared to the native cellulose, so it can be used in various areas (Iguchi et al., 2000). In particular, the formed BC aerogels were dried gels with high porosities, large surface areas, and extremely light weights. It is an ideal material for formation 
aerogel due to its renewable, biocompatible, and biodegradable properties. The aerogel was prepared using a sodium hydroxide/urea method (Isobe et al., 2012) due to the low cost and convenience of the technique.

When the BC is coated with MTMS, it will become hydrophobic and oleophilic and therefore, has a good affinity to oil. The MTMS-coated BC aerogel was used for the oil absorption test. Water and oil absorption tests showed that the uncoated and the coated aerogels have high liquid absorption capacities of 6-7 times their own weights and can be easily reused by a simple squeezing or drying to remove the absorbed liquid (Nguyen et al., 2014).

There is a demand to synthesize new absorbent materials with high absorption capacity and easy water removal (Zhang et al., 2012). Additionally, the aerogels are dried gels with high porosities, large surface areas, and extremely light weights (Baetens et al., 2011). Consequently, the BC produced by G. xylinus applied in aerogel formation. Water absorbed by the BC aerogel is removed easily by simply squeezing it (Nguyen et al., 2014). Although no cross-linkers were used in the synthesis, the aerogel preserved its shape after being immersed in water for $2 \mathrm{~h}$, indicating that the material has a stable structure due to the cellulose-cellulose hydrogen bonding (Chen et al., 2011). Furthermore, the BC based aerogels have also been used as adsorbents to remove pollutants from aqueous systems. Zhao et al. (2015) cellulose aerogels with high porosity and large specific surface area have been used for $\mathrm{Cr}$ (VI) removal.

On the other side, the $\mathrm{pH}$ of the solution had been reported to be important factor in adsorption processes. The variations in adsorption capacity of BC aerogel with increasing $\mathrm{pH}$ could be inferred that the adsorption capacity increased as solution $\mathrm{pH}$ increased from $\mathrm{pH} 4$ to 6 and capacity decreases above $\mathrm{pH}$ 6. Similar observation has been previously reported by Luzny et al. (2014). With an increase in the $\mathrm{pH}$, the negative charge density on the adsorbent increased due to the deprotonation of the metal binding sites, leading to the increase of metal adsorption (Salehzadeh, 2013).

Finally, this work was extended to investigate the fate of the G. xylinus BC in the environment. Our data exhibited that fresh water microbes had highest effect for BC biodegradation within 15 days. Basically, the bacteria, fungi, and actinomycetes can degrade cellulosic wastes in the environment to use them as a source of carbon and energy include a variety of aerobes and anaerobes, mesophiles and thermopiles (Gold et al., 2000; Gutierrez et al., 2001). It has been reported that several fungi such as Trichoderm spp, Aspergillus spp, Aspergillus chaetomium, Aspergillus fumigatus, Aspergillus flavus, Curvularia, Fusarium, Memoniella sp, Phomo sp, Thielavia sp., and Penicillium spp. degraded cellulose (Makeshkumar and Mahalingam, 2011; Wilson, 2011). Also, results obtained by Srikandace et al. (2018) showed that fungi biodegraded BC films through broth fermentation whereas no biodegradation activity on solid substrate fermentation. Collins and Charles (2017) identified cellulose-degrading bacteria as Bacillus brevis, Bacillus coagulans, Bacillus laterosporus, Bacillus firmus, 
Pseudomonas mallei, Pseudomonas putida, Cellulomonas fimi, and Cellulomonoas flavigena from the soil containing old rice husk dump within 60 days. All those support the safe usage of the BC produced by G. xylinus ATCC 10245 on the environment.

\section{CONCLUSION}

Aiming to improve BC production, the cell immobilization of G. xylinus by entrapment or adsorption techniques was studied. The highest BC productivity (14.5 g/l) was observed in cells immobilized LP as a solid support. The productivity was about 1.14-fold of that obtained from free cells. The immobilized cells were reused for 2 successive cycles covering a period of 30 days. At second cycle on LP, the BC production reached about $15.7 \mathrm{~g} / \mathrm{l}$, and about 1.24 -fold. However, a gradual decrease in $\mathrm{BC}$ production was observed in the next reuses. Scanning electron microscope indicated the good adsorption of bacterial cells to the surface of LP with different degrees.

Some properties of the BC produced by G. xylinus were studied well. Significantly, it had high water absorption capacity (199\%) with good tensile strength (22.7 MPa) and young's modulus (349.5 MPa). So, these properties enable G. xylinus BC for a potential application in paper industry to produce parchment paper.

On the other side, the formation of $\mathrm{BC}$ aerogels was conducted and its characteistics of water absorption capacity and oil absorption ability qualify to be used in diapers industry. In addition, the adsorption potential of $\mathrm{BC}$ aerogel in the removal of heavy metal ions $\left(\mathrm{Pb}^{2+}, \mathrm{Cd}^{2+}\right.$, and $\left.\mathrm{Cu}^{2+}\right)$ from aqueous solution.

Inclusively, this work may provide relevant scientific information about the usage of produced BC by G. xylinus cells in the Egyptian market, such as a paper-making industry, and diapers. Because the aerogels have ability to absorb oil spills, they can be effectively used in the purification and treatment of wastewater from heavy metals.

\section{REFERENCES}

Alemán, J.; He, J.; Hess, M. and Jones, R.G. (2006). Definitions of terms relating to the structure and processing of sols, gels, networks, and inorganic-organic hybrid materials. Pure Appl. Chem., 79 (10). 1801 -1827.

Baetens, R.; Jelle, B.P. and Gustavsen, A. (2011). Aerogel insulation for building applications: A state-of-the-art review, Energ. Buildings., 43: 761-769.

Beliah, M. (2017). Production of Biocellulose Nanofibers Using Marine Wastes Fermented by Gluconacetobacter xylinus. PhD thesis. Facultyof Science,Alexandria Uiversity, Egypt.

Beliah, M.; Ibrahim, H.; Farag, A.M.; ElAhwany, A. and Sabry. S. (2020). Utilization of marine algae as a carbon source for bacterial cellulose production by Gluconacetobacter xylinus.Egypt. J. Aquat. Biol. Fish., 24:497-518.

Berekaa, M.M.; El Aassar, S.A.; El-Sayed, S.M. and EL Borai, A.M. (2009). Production of Poly- $\gamma$-Glutamate (PGA) Biopolymer by batch and semicontinuous 
cultures of immobilized Bacilluslicheniformis strain-R. Braz.J.Microbiol.,40: 715724.

Bielecki, S.; Krystynowicz, A.; Turkiewicz, M. and Kalinowska, H. (2005). Bacterial cellulose. In: polysaccharides and polyamides in the food industry, A. Steinbüchel, S.K. Rhee (Eds.), Wiley-VCH Verlag, Weinheim, Germany.

Chawla, P.R.; Bajaj, I.B.; Survase, S.A. and Singhal, R.S. (2009). Fermentative production of microbial cellulose, Food Technol. Biotechnol., (2): 107-124.

Chen, S.B.; Ma, Y.B.; Chen, L. and Xian, K. (2010). Adsorption of aqueous $\mathrm{Cd}^{2+}$, $\mathrm{Pb}^{2+}, \mathrm{Cu}^{2+}$ ions by nano-hydroxyapatite: Single- and multi-metal competitive adsorption study. Geochem. J., 44: 233-239.

Chen, W.; Yu, H.; Li, Q.; Liu, Y. and Li, J. (2011). Ultralight and highly flexible aerogels withlong cellulose I nanofibers. Soft Matter., 7: 10360-10368.

Chitturi, C.M.K. and Lakshmi, V.V. (2016). Immobilization of bacilli in various matrices to enhance the utilization of keratinase and its comparison Int. J.Curr.Microbiol.App.Sci., 5: 389-396.

Collins, O.N. and Charles, C.O. (2017). Phenotypic characterization of mesophilic bacteria species involved in the biodegradation of rice husk from Abakaliki Rice Mill Ebonyi State South East Nigeria. Idosr J. Biol. Chem. Pharma., 1(1): 23-37.

Czaja, A.; Krystynowicz, S.; Bielecki, R.M. and Brown, J.r. (2006). Microbial cellulose - The natural power to heal wounds. Biomater., 27: 145-151.

El-Naggar, M.M.; Abdul-Raouf, U.M.; Ibrahim, H.A.H.; and El-Sayed, W.M.M. (2014). Saccharification of Ulva lactuca via Pseudoalteromonas piscicida for biofuel production. J. Energy Nat.Resour., 3: 77-84.

Enas, A.H.; Hemmat, M.A.; Sohir, S.A. and Sara, M.A. (2015). The characterization of bacterial cellulose produced by Acetobacter xylinum and Komgataeibacter saccharovorans under optimized fermentation conditions. British. Microbiol. Res. J., 9: 1-13.

Esa, F.; Tasirin, S.M. and Abd Rahman, N. (2014). Overview of Bacterial Cellulose Production and Application. Agric. Agric. Sci., Procedia. 2: 113 - 119.

French, A.D. (2014). Idealized powder diffraction patterns for cellulose polymorphs. Cellul. Chem. Technol., 21: 885-896.

Gold, M.H.; Youngs, H.L.; Sollewijin, I. and Gelpke, M.D. (2000). Manganese peroxidase. In: Sigel, A, Sigel H (Eds). Metal ions biological systems. Marcel Dekker, New York, pp. 559-587.

Górecka, E. and Jastrzębska, M. (2011). Immobilization techniques and biopolymer carriers. Biotechnol. Food Sci., 75: 65-86.

Goyat, M.(2016). Production of green bacterial cellulose nanofibers by utilizing renewable resources of algae in comparison with agricultural residue. MSc thesis. Program of Chemical Engineering, Toronto, Ontario, Canada.

Gutierrez, A.; del Rio, J.C.; Martinez, M.J. and Martinez, A.T. (2001). The biological control of pitch in paper pulp manufacturing. Trend Biotechnol.,19: 340-348.

Halib, N.; Mohd, C.I.; Mohd, A. and Ishak, A. (2012). Physicochemical properties and characterization of Nata de Coco from local food industries as a source of cellulose. Sains Malaysiana., 41:205-211.

Hungund, B.; Prabhu, S.; Shetty, C.; Acharya, S.; Prabhu, V. and Gupta, S.G. 
(2013). Production of bacterial cellulose from Gluconacetobacter persimmonis GH-2 using dual and cheaper carbon sources. J. Microb. Biochem Technol., 5: 3133.

Iguchi, M.; Yamanaka, S. and Budhiono, A. (2000). Bacterial cellulose a masterpiece of nature's arts. J. Mater. Sci., 35: 261-270.

Isobe, N.; Kimura, S.; Wada, M. and Kuga, S. (2012). Mechanism of cellulose gelation from aqueous alkali-urea solution. Carbohydr. Polym., 89: 1298-1300.

Johnson, D.C. (1985). Solvents for cellulose. In: Cellulose chemistry and its applications Nevell, T.P \&Zeronian, S.H. (Eds). New York, Ellis Horwood Limited.

Jung, J.Y.; Park, J.K. and Chang, H.N. (2005). Bacterial cellulose production by Gluconoacetobacter hansenii in an agitated culture without living non-cellulose producing cells. Enzyme. Microb. Technol., 37: 347-354.

Keshk, S. (2006). Physical properties of bacterial cellulose sheets produced in presence of lignosulfonate. Enzyme. Microb. Technol., 40:9-12.

Khan, S.; Ul-Islam, M.; Khattak, W.A.; Ullah, M.W.; Yu, B. and Park, J.K. (2015). Enhanced bio-ethanol production via simultaneous saccharification and fermentation through a cell free enzyme system prepared by disintegration of waste of beer fermentation broth. Korean J. Chem. Eng., 32: 694-701.

Lee, R. A., \& Lavoie, J. M. (2013). From first-to third-generation biofuels: Challenges of producing a commodity from a biomass of increasing complexity. Animal Frontiers, 3(2): 6-11.

Lin, S.B.; Hsu, C.P.; Chen, L.C. and Chen, H.H. (2009). Adding enzymatically modified gelatin to enhance the rehydration abilities and mechanical properties of bacterial cellulose. Food Hydrocolloids., 23: 2195-2203.

Luzny, R.; Ignasiak, M.; Walendziewski, J. and Stolarski, M. (2014). Heavy metal ions removal from aqueous solutions using carbon aerogels and xerogels. CHEMIK., 68(6): 544-553.

Makeshkumar V. and Mahalingam P.U. (2011). Isolation and characterization of rapid cellulose degrading fungal pathogens from compost of agro wastesIsolation and characterization of rapid cellulose degrading fungal pathogens from compost of agro wastes. Int. J. Pharma. Biol. Archives, 2(6): 1695-1698.

Miller, G.L. (1959). Use of dinitrosalicylic acid for determination of reducing sugar. Anal. Chem., 31: 426-428.

Mistriotis, A. and Briassoulis, D. (2014). Review of Standard Testing methods and specifications for measuring biodegradation of bio-based materials in fresh water. Proceedings International Conference of Agricultural Engineering, Zurich.

Mohammad, S.M.; Rahman, N.A.; Khalil, M.S. and Abdullah, S.R.S. (2014). An Overview of biocellulose production using Acetobacter xylinum culture. Adv. Biol. Res., 8: 307-313.

Moosavi-Nasab, M. and Yousefi, A. (2011). Biotechnological production of cellulose by Gluconacetobacter xylinus from agricultural waste. Iran. J. Biotechnol., 9: 94101.

Mormino, R. and Bungay, H. (2003). Composites of bacterial cellulose and paper made with a rotating disk bioreactor. Appl. Microbiol. Biotechnol., 62: 503-506.

Mrudula, S. and Shyam, N. (2012). Immobilization of Bacillus megaterium MTCC 2444 by Ca-alginate entrapment method for enhanced alkaline protease 
production. Braz. Arch. Biol. Technol., 55: 135-144.

Nge, T.T.; Sugiyama, J. and Bulone, V. (2010). Bacterial cellulose-based biomimetic composites. In Biopolymers, ElNashar M, (Ed.). Sciyo, pp. 345-368.

Nguyen, S.T.; Feng, J.; Ng, S.K.; Wong, J.P.W.; Tan, V.B.C.; Hai, M. and Duong, H.M. (2014). Advanced thermal insulation and absorption properties of recycled cellulose aerogels. Colloids and SurfacesA: Physicochem. Eng. Aspects., 445: $128-134$

Salehzadeh, J. (2013). Removal of heavy metals $\mathrm{Pb}^{2+}, \mathrm{Cu}^{2+}, \mathrm{Zn}^{2+}, \mathrm{Cd}^{2+}, \mathrm{Ni}^{2+}, \mathrm{Co}^{2+}$ and $\mathrm{Fe}^{3+}$ from aqueous solutions by using Xanthium pensylvanicum. Leonardo. J. Sci., 12:97-104.

Sankaralingam, S.; Shankar, T.; Sendeshkannan, K.; Ramasubburayan, R. and Prakash, S. (2012). Production of protease from Pseudomonas sp. by immobilization approach on different matrices. Euro. J. Appl. Sci., 4: 146-156.

Schröpfer, S.B.; Bottene, M.K.; Bianchin, L.; Robinson, L.C.; Lima, V.; Jahno, V.D.; Barud, H.S. and Ribeiro, S.J.L. (2015). Biodegradation evaluation of bacterial cellulose, vegetable cellulose and poly (3-hydroxybutyrate) in soil. Polímeros., 25: 154-160.

Shah, R.M. and Brown, J.r. (2005). Towards electronic paper displays made from microbial cellulose. Appl. Microbiol. Biotechnol.,66: 352-355.

Srikandace, Y.; Andayani, D.G.S. and Karina, M. (2018). Preliminary study of the degradation of biocellulose based film using soil fungi Aspergillus unguis TP3 and Paecilomyces marquandii TP4 producing cellulose. 3rd International Symposium on Green Technology for Value Chains 2018. IOP Conf. Series: Earth and Environmental Science 277 (2019) 012001.

Stolarzewicz, I.; Bialecka-Florjañczyk, E.; Majewska, E. and Krzyczkowska, J. (2011). Immobilization of yeast on polymeric supports. Chem. Biochem. Eng., 25: $135-144$.

Suwannapinun, N.; Burakorn, J. and Thaenthanee, S. (2007). Effect of culture conditions on bacterial cellulose (Bc) production from Acetobacter xylinumTistr976 and physical properties of Bc parchment paper. Suranaree J. Sci. Technol., 14: 357-365.

Suwanposri, A.; Yukphan, P.; Yamada, Y. and Ochaikul, D. (2014). Statistical optimization of culture conditions for biocellulose production by Komagataeibacter sp. PAP1 using soya bean whey. Maejo Int. J. Sci. Technol., 8: $1-14$.

Szulczyk, K. R. (2010). Renewable and sustainable reviews. Market penetration of biodiesel., 14(8): 2426-2433.

Tan, C.; Fung, B.M.; Newman, J.K. and Vu, C. (2001). Organic aerogels with very high impact strength. Advanced Materials., 13: 644-646.

Tsouko, E.; Kourmentza, C.; Ladakis, D.; Kopsahelis, N.; Mandala, I.; Papanikolaou, S.; Paloukis, F.; Alves, V. and Koutinas, A. (2015). Bacterial cellulose production from industrial waste and by-product streams. Int. J. Mol. Sci., 16: 14832-14849.

Ul-Islam, M.; Khan, T. and Park, J.K. (2012). Water holding and release properties of bacterial cellulose obtained by in situ and ex situ modification. Carbohyd. Polym.,88: 596-603. 
Ullah, M.W.; UI Islam, M.; Khan, S.; Kima, Y. and Parka, J.K. (2016). Structural and physic mechanical characterization of bio-cellulose produced by a cell-free system. Carbohyd. Polym., 136: 908-916.

Vassilev, N.B.; Vassilev, M.C. and Spassova, D.I. (1993). Production of gluconic acid by Aspergillus niger immobilized in polyurethane foam. Appl. Microbiol. Biotechnol., 39: 285-288.

Wada, M.; Kato, J. and Chibata, I. (1980). Continuous production of ethanol using immobilized growing yeast cells. Eur. J. Appl. Microbiol., 10:275-287.

Wilson, D.B. (2011). Microbial diversity of cellulose hydrolysis.Curr. Opin. Microbiol., 14: 259-263.

Wu, J.; Zheng, Y.; Song, W.; Luan, J.; Wen, X.; Wu, Z.; Chen, X.; Wang, Q. and Guo, S. (2014). In situ synthesis of silver-nanoparticles/bacterial cellulose composites for slow-released antimicrobial wound dressing. Carbohydrate polym., 102: 762-771.

Wu, J.M. and Liu, R.H. (2012). Thin stillage supplementation greatly enhances bacterial cellulose production by Gluconacetobacter xylinus. Carbohydrate polym., 90: 116-121.

Zeng, X.; Small, P. and Wan, W. (2011). Statistical optimization of culture conditions for bacterial cellulose production by Acetobacter xylinum BPR 2001 from maple syrup. Carbohydr. Polym., 85: 506-513.

Zhang, W.; Zhang, Y.; Lu, C. and Deng, Y. (2012). Aerogels from cross linked cellulosenano/micro-fibrils and their fast shape recovery property in water. $\mathrm{J}$. Mater. Chem., 22: 11642-11650.

Zhao, J.; Zhang, X.; He, X.; Xiao, M.; Zhang, W. and Lu, C. (2015). A super biosorbent from dendrimer poly (amidoamine)-grafted cellulose nanofibril aerogels for effective removal of Cr (VI). J. Mater. Chem., 3: 14703-14711. 